\title{
ELECTRODIAGNOSIS AT MEDIAN OCCLUSAL POSITION FOR HUMAN SUBJECTS WITH MANDIBULAR JOINT SYNDROME
}

\author{
D. C. MCNamara* \\ Departments of Occlusion and Bioengineering, The University of Michigan, Ann Arbor. Michigan. \\ U.S.A.
}

\begin{abstract}
Summary--Neuromuscular inhibitory effects were monitored in the temporalis and masseter muscles for ten patients with mandibular joint (MJ) syndrome. and ten control subjects with normal occlusions. Analysis of the electromyographic (EMG) silent period in the controls showed no significant difference hetween durations at median occlusal position, following placement of a maxillary acrylic occlusal splint, and during gum chewing. However, for the patients with MJ syndrome, there was an immediate decrease in their mean EMG silent-period duration upon placement of the splint from $19.23 \mathrm{msec}$ to $15.52 \mathrm{msec}$. This shortened duration was the same with or without a splint after the pain symptoms had subsided. Precise occlusal adjustment of the dentition at the pain-free appointment resulted in a further reduction 110.83 msec) to within the range of the normal control subjects at median occlusal position. Inhibitory pauses during gum chewing showed similar treatment interactions but, during some chewing cycles, no silent periods were evident.
\end{abstract}

\section{INTRODUCTION}

The aetiology of mandibular joint (MJ) syndrome is considered to be multifactorial and several concepts are necessary to explain the pain-dysfunction symptoms (De Boever, 1973). These concepts include (1) mechanical displacement of the condyles due to lack of bilateral support by the dentition, (2) muscle imbalance due to hypokinetic disease, (3) neuromuscular disharmony of the masticatory components, (4) psychophysical hyperactivity or spasms of the masticatory musculature and (5) psychological factors which lead to parafunctional mandibular movements. The frequency of joint and muscle symptoms increases with the dysfunction index. and are equally common in both sexes (Helkimo, 1974).

Lack of harmory between the teeth, mandibular joint and neuromuscular function, is considered to be the triggering factor for functional disorders of the masticatory system (Shore, 1959: Schwartz and Chayes, 1968; Krough-Poulsen and Carlsen, 1974); furthermore, neuromuscular changes are observed with pain-dysfunction symptoms and in potential MJ dysfunction patients (Griffin and Munro, 1971; 1972). Conservative occlusal treatment is a recommended form of therapy for functional disturbances of the joints and muscles (Ramfjord and Ash, 1971; Dawson, 1974). In healthy individuals, median occlusal position is assumed to be that position of harmony for the dentition, MJ and masticulatory musculature, from which precise: jaw movements commence and automatically terminate (Sicher and Du Brul, 1975). However, occlusal adjustment procedures do not investigate this physiological position of neuromuscular integrity.

The purpose of this pilot study was to quantify the neuromuscular inhibitory response at median

*Present Address: 1 Felton Road, City Beach, Western Australia occlusal position for significance to diagnosis in patients with mandibular joint syndrome, before and after conservative occlusal treatments.

\section{MATERIALS AND MFTHODS}

Ten control subjects (eight females and two males) with normal occlusions, were selected with no previous history of $\mathrm{MJ}$ syndrome. None of their teeth had complete occlusal coverage restorations, and there were no clinically detectable occlusal supracontacts. The subjects were furnished with maxillary acrylic occlusal splints, which were adjusted for even contact during terminal hinge closure (Ramfjord and Ash, 1971). The examination procedures were: (1) to achieve median occlusal position, by opening rather wide and snapping shut automatically, (2) to perform the same jaw-closing with the maxillary splint inserted. and (3) to chew gum forcefully. During these procedures, bilateral electromyographic (EMG) recordings were made from their temporalis, masseter and anterior digastric muscles, while jaw position and the exact contact of the dentition was monitored with a Hall-effect device (McNamara, 1976a).

Ten patients (again eight females and two males of similar age) with mandibular joint syndrome were examined as above, performing the procedures as best they could, limited by the severity of their painful limitation of jaw motion. The patients were instructed to wear the maxillary acrylic occlusal splint as much as was possible, and were recalled at intervals ranging from 2 to 7 days to adjust the splints, until all pain symptoms had subsided. The three examination procedures were recorded at this pain-free stage. With the EMG electrodes still in position, the occlusion was adjusted (McNamara, 1976b) to eliminate supracontacts to an accuracy of $0.00127 \mathrm{~mm}$ plastic shimslock (The Artus Corp., Englewood, New Jersey, U.S.A.); then the examination procedures were 
Table 1. Cell means (msec) EMG silent-period durations for the normal control subjects.

\begin{tabular}{lrcr}
\hline \multicolumn{1}{c}{ Procedures } & $\begin{array}{c}\text { Median } \\
\text { occlusal } \\
\text { position }\end{array}$ & $\begin{array}{c}\text { Maxillary } \\
\text { acrylic } \\
\text { splint }\end{array}$ & $\begin{array}{c}\text { Gum } \\
\text { chewing }\end{array}$ \\
\hline Muscles examined & & & \\
Right temporalis & 9.21 & 11.50 & 10.03 \\
Left temporalis & 9.21 & 10.65 & 10.01 \\
Right masseter & 10.02 & 10.11 & 9.57 \\
Left masseter & 10.13 & 10.90 & 9.63 \\
\hline
\end{tabular}

repeated. Using an analysis of variance computer program (BMD 08V University of Michigan IBM 360/67 time-sharing computer system) for nested and fully crossed designs of equal cell sizes, statistical comparisons were made.

\section{RESULTS}

The ten normal subjects had no significant difference $(F=2.17$ on 2 and 16 d.f.) in their mean silentperiod durations at median occlusal position, with an occlusal splint inserted, and with forceful gum chewing (Table 1). During the gum chewing, silent periods were not evident in every chewing cycle; therefore any five cycles with inhibitory pauses were selected for statistical analysis (Fig. 1).

The ten patients with $\mathrm{MJ}$ syndrome showed an immediate decrease of mean silent period duration upon insertion of the maxillary acrylic splint (Table 2, cell mean $19.23 \mathrm{msec}$ decreased to $15.52 \mathrm{msec}$ ). This duration was the same as when there was relief of all pain symptoms-some two to twelve weeks later (cell mean $15.54 \mathrm{msec}$ for the three procedures examined). Occlusal adjustment at this pain-free appoint-
Table 2. Cell means (msec) EMG silent period durations grouped for all the muscles examined in the patients with $\mathrm{MJ}$ syndrome.

\begin{tabular}{|c|c|c|c|}
\hline Procedures & $\begin{array}{l}\text { Median } \\
\text { occlusal } \\
\text { position }\end{array}$ & $\begin{array}{c}\text { Maxillary } \\
\text { acrylic } \\
\text { splint }\end{array}$ & $\begin{array}{c}\text { Gum } \\
\text { chewing }\end{array}$ \\
\hline \multicolumn{4}{|l|}{ Treatments effects } \\
\hline $\begin{array}{l}\text { First EMG analysis } \\
\text { with pain symptoms }\end{array}$ & 19.23 & 15.52 & 16.72 \\
\hline \multicolumn{4}{|c|}{$\begin{array}{l}\text { Second EMG analysis, after splint therapy and with- } \\
\text { out pain symptoms }\end{array}$} \\
\hline $\begin{array}{l}\text { Before occlusal } \\
\text { adjustment }\end{array}$ & 15.59 & 15.62 & 15.40 \\
\hline $\begin{array}{l}\text { After occlusal } \\
\text { adjustment }\end{array}$ & 10.83 & 15.11 & 10.83 \\
\hline
\end{tabular}

ment resulted in a further decrease of the mean silentperiod duration at median occlusal position (10.83 $\mathrm{msec}$ ). During gum chewing, the same trend of reduction of silent-period duration occurred following loss of pain symptoms (mean $15.4 \mathrm{msec}$ ), and elimination of occlusal interferences (mean $10.83 \mathrm{msec}$ ). Thus, for the MJ syndrome patients, the effect of conservative occlusal therapy was to reduce significantly the duration of the EMG silent period $(\mathrm{F}=22.82$ on 3 and 24 d.f. $p<0.001$ ). The procedure-treatment interaction was highly significant $(F=5.13$ on 4 and 32 d.f. $p<0.01$ ) with a lack of parallelism due to the maxillary acrylic splint procedure. Analysis of the effect of the splint by itself revealed no significant $(F<1)$ reduction of the silent period with the splint inserted (Table 3 ). However, grouping the muscles as pain side, and contralateral, according to the severity of $\mathrm{MJ}$ symptoms, resulted in a significant difference

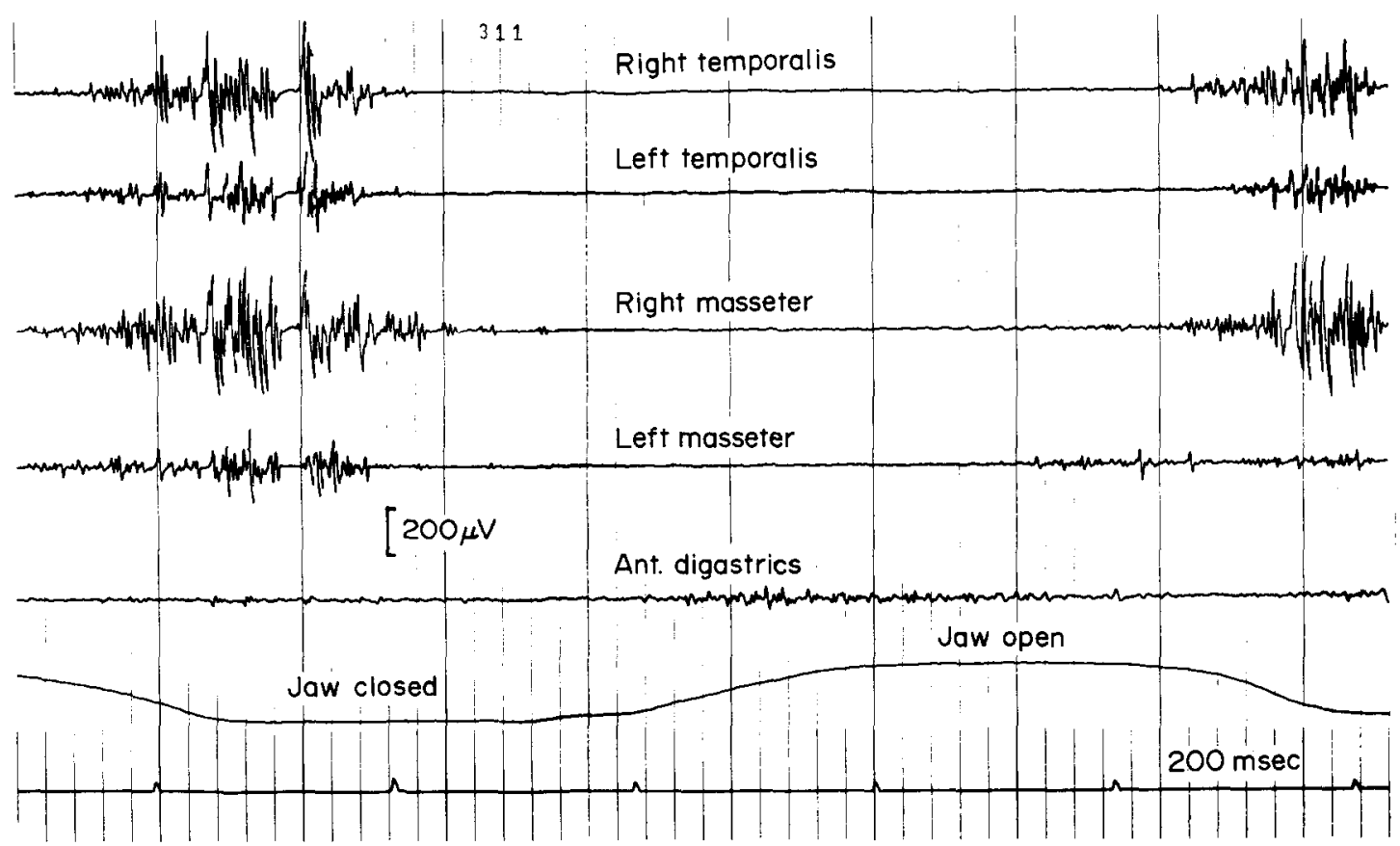

Fig. 1. Two consecutive gum chewing cycles, with presence and absence of marked EMG silent periods 
Table 3. Cell means (msec) EMG silent period durations for the MJ syndrome patients, with a maxillary acrylic occlusal splint inserted.

\begin{tabular}{cccc}
\hline $\begin{array}{c}\text { Treatments } \\
\text { effects }\end{array}$ & $\begin{array}{c}\text { Initial } \\
\text { splint } \\
\text { insertion }\end{array}$ & $\begin{array}{c}\text { Following } \\
\text { splint } \\
\text { treatment }\end{array}$ & $\begin{array}{c}\text { Following } \\
\text { occlusal } \\
\text { adjustment }\end{array}$ \\
\hline $\begin{array}{c}\text { Muscles examined } \\
\text { Joint-pain-side } \\
\text { temporalis }\end{array}$ & 17.11 & 16.09 & 15.81 \\
$\begin{array}{c}\text { Contralateral } \\
\text { temporalis }\end{array}$ & 14.72 & 15.59 & 15.42 \\
$\begin{array}{c}\text { Joint-pain-side } \\
\text { masseter }\end{array}$ & 15.99 & 15.38 & 14.50 \\
$\begin{array}{c}\text { Contralateral } \\
\text { masseter }\end{array}$ & 14.25 & 15.42 & 14.71 \\
\hline
\end{tabular}

in their EMG silent-period durations $(F=4.13$ on 3 and 24 d.f. $p<0.025$ ).

\section{DISCUSSION}

The treatment irteraction of a decrease in the silent period duration for the $\mathrm{MJ}$ syndrome patients upon relief of their pain symptoms, is similar to alterations in the silent period elicited by a standardised jaw-jerk reflex (Besette, Bishop and Mohl, 1971). This is further supported by the study where experimentally introduced occlusal splint interferences resulted in pain symptoms and an increase in the silent-period duration (Drechsler et al., 1973).

The mandibular joint syndrome patients whose symptoms had subsided revealed that elimination of occlusal supracontacts were necessary to reduce the EMG silent-period duration (mean $10.82 \mathrm{msec}$ ) to within the range of the normal subjects (mean 9.64 msec) at median ocslusal position. Therefore. not only should the various occlusal positions as advocated by Ramfjord (1961) in occlusal adjusted procedures be considered, but also median occlusal position, due to its anatomical and neuromuscular significance.

The similarity in treatment interaction of the mean silent-period duration at median occlusal position and during gum chewing suggests a well-established functional neuromuscular reflex pattern. This agrees with the concept of perpetual reinforcement of the patterns of neural firing during function to instigate median occlusal position (Sicher and Du Brul, 1975). Any functional tooth contact of sufficient stimulus would cause a silent period (Shaerer et al., 1967). Periodontal neural complexes are suggested to be responsible for the jaw-opening reflex following tooth contact (Harris and Griffin, 1974). However, Bratzlavsky (1972) concludes that the silent period in jaw-closing muscles can be explained on the basis of the pause in spindle afferent discharge. As direct recording can be made of muscle spindle afferents (Vallbo and Hagbarth, 1968), study of individual motor unit excitability related to the silent-period duration is possible (Erbel and Stuppler 1970). The vast complexity of excitatory and inhibitory influences on motoneurones involved in the normal human EMG silent period is indicated in a review by Shahani and Young (1973).
In particular, the duration of the masseter silent period is associated with changes in central neural activity produced by proprioceptive and sensory input from the stimulus upon the degree of muscle tension. Thus, the silent-period duration of the temporalis and masseter muscles varied significantly with relief of pain symptoms and adjustment of the dentition at median occlusal position. Furthermore, problems of psychophysiology must also be considered, such as the subjective lower pain thresholds and reduced muscle forces together with personality traits of patients with MJ syndrome (Molin, 1973).

In conclusion, the mean EMG silent-period duration of the patients with TMJ syndrome was prolonged. There was a decrease in duration after the pain symptoms had subsided. Further precise occlusal adjustment of the dentition was necessary to reduce the EMG silent-period duration to within the range of normal subjects at median occlusal position. This electrophysiologic procedure provided a quantitative neuromuscular assessment of conservative occlusal therapy.

Acknowledgements-I wish to thank Dr. C. J. Kowalski who directed the statistical analyses and N. Steinhouse who helped with interpretation. Dr. P. J. Henry kindly assisted in preparation of this report. This work was supported in part by USPHS Grant DE-02731.

\section{REFERENCES}

Besette R., Bishop B. and Mohl N. 1971. Duration of masseteric silent period in patients with TMJ syndrome. $J$. appl. Physiol. 30, 864-869.

Bratzlavsky M. 1972. Pauses in activity of human jaw closing muscles. Expl. Neurol. 36, 160-165.

Dawson P. E. 1974. Evaluation, Diagnosis, and Treatment of Occlusal Problems. C.V. Mosby Company. Saint Louis.

De Boever J. 1973. Functional disturbances of the temporomandibular joints. Oral Sci. Rev. 2, 100-117.

Drechsler V F.. Kohno S., Kühl and Neuhauser B. 1973. Neurophysiologische Analyse der Wirkungen Okklusaler Interferenzen auf Regulation and Koordination der Kaumuskulatur. Dt. Zahn. Z. 28. 695-704.

Erbel F. and Stuppler A. 1970. Weitere Untersuchungen zum Entlastungsreflex am menschen. Pfiugers Arch. ges. Physiol. 316. 59

Griffin C. J. and Munro R. R. 1971. Electromyography of the masseter and anterior temporalis muscles in patients with temporomandibular dysfunction. Archs oral Biol. 16. 929-949.

Harris R. and Griffin C. J. 1974. Innervation of the human periodontium. IV. Fine structure of the complex mechanoreceptors and free nerve endings. Aust. dent. J. 19 (5). $326-331$.

Hclkimo M. 1974. Studies on function and dysfunction of the masticatory system. Thesis, Department of Stomatognathic Physiology, University of Göteborg.

Krogh-Poulsen W. and Carisen O. 1974. Bidfunktion Bettfysiologi II. Munksgaard. Copenhagen.

McNamara D. C. 1976 (a) Inhibitory effects in the masticatory neuromusculature of human subjects at median occlusal position. Archs oral Biol. 21, 329-331.

McNamara D. C. 1976 (b) Adjustment of human dentitions for a physiologically balance occlusion. J. prosth. Dent. in press.

Molin C. 1973. Studies in mandibular pain dysfunction syndrome. Thesis, Swedish dent. J. Supplement 4, 66. $1-55$. 


\section{C. McNamara}

Munro, R. R. 1972. Electromyography of the masseter and anterior temporalis muscles in subjects with potential temporomandibular joint dysfunction. Aust. dent. J.. 17. (3), 209-218.

Ramfjord S. P. 1961. Dysfunctional temporomandibular joint and muscle pain. J. prosth. Dent. 11. 353-374.

Ramfjord S. P. and Ash Jr. M. M. 1971. Occlusion, 2nd Edn. Chap 11. p. 245-251. Saunders, Philadelphia.

Schwartz L. and Chayes C. M. 1968. Facial Pain and Mandibular Disfunction, W. B. Saunders Company. Philadelphia

Shaerer P., Stallard R. E. and Zander H. A. 1967. Occlusal interferences and mastication: An electromyographic study. J. prosth. Dent. 17. 438-449.
Shahani B. T. and Young R. R. 1973. Studies of the normal human silent period. New Developments in Electromyography and Clinical Neurophysiology. 3. 589-602. Karger, Basel.

Shure N. A. 1959. Occlusal Equilibration and Temporomandihular Joint Dysfunction. J. B. Lippincott, Philadelphia. Sicher H, and Du Brul E. L. 1975. Oral Anatomy. 6th Edn Chap. 4, p. 187-191. C.V. Mosby Company, Saint Louis. Vallbo $\AA$. B. and Hagabarth. K. E. 1968. Activity from skin mecharoreceptors recorded percutaneously in awake human subjects. Expl. Neurol. 21. 270-289. 